\title{
Spatial and temporal distribution of fishing resources exploited by the Manaus fishing fleet, Amazonas, Brazil
}

\author{
Batista, VS. ${ }^{\text {a* }}$ and Petrere $\mathrm{Jr}, \mathrm{M}^{\mathrm{b}}{ }^{\mathrm{*}}$ \\ anstituto de Ciências Biológicas e da Saúde, Praça Afrânio Jorge s/n, Universidade Federal de Alagoas, \\ CEP 57010-020, Maceio, AL, Brazil \\ bepartamento de Ecologia, Campus Rio Claro, Universidade Estadual Paulista - UNESP, \\ CP 199, CEP 13506-900, Rio Claro, São Paulo, Brazil \\ *e-mail: vbatista@pq.cnpq.br, mpetrere@ rc.unesp.br
}

Received November 24, 2005 - Accepted April 10, 2006 - Distributed November 30, 2007

(With 2 figures)

\begin{abstract}
Fishing resources are important generators of income and food for the rural and urban people in the Amazon. The present paper investigates fishing and environmental variables determining fishing production landed in Manaus and evaluates the relative abundance of commercial fishes in the different sub-systems of the Central Amazon basin. Information collected was used to test the new catch index derived from multiple regressions with the following significant variables: number of fisherman days fishing; distance of the fishing ground from Manaus; amount of ice carried during the trip; and river level. There were no significant differences between mean catch values of the Purus, Madeira and Juruá sub-systems. These results suggest that the tributaries of the right margin were very similar and were the most productive in commercial terms. The actual production varies according to the recent magnitude of fishing effort, environmental variations and operational aspects of fishing, particularly ice consumption.
\end{abstract}

Keywords: distribution, fishes, Amazon, fishing fleet, large rivers.

\section{Distribuição espacial e temporal de recursos pesqueiros explorados pela frota pesqueira de Manaus, Amazonas, Brasil}

\section{Resumo}

Recursos pesqueiros são importantes fontes de renda e alimento para as populações rurais e urbanas na Amazônia. O presente trabalho avalia a pesca e as variáveis ambientais que determinam a produção de pescarias que desembarcam em Manaus, e avalia também a abundância relativa de recursos pesqueiros em diferentes subsistemas na Amazônia Central. A informação coletada no porto de desembarque de pescado de Manaus foi utilizada para testar um novo índice de captura obtido a partir de um modelo de covariância que apresentou as seguintes variáveis significativas: número de pescadores/dia (dias de pesca vezes número de pescadores por viagem); distância do pesqueiro até Manaus; quantidade de gelo que usou durante a viagem; e nível de rio. Não houve nenhuma diferença significativa entre valores médios de captura entre os subsistemas do Purus, Madeira e de Juruá. Estes resultados sugerem que os tributários da margem direita são similares e mais produtivos em termos comerciais. Concluiu-se que a produção corrente varia de acordo com a magnitude de esforço pesqueiro, por variações ambientais, assim como por aspectos operacionais da pesca, particularmente o consumo de gelo.

Palavras-chave: distribuição, peixes, Amazônia Central, frota pesqueira, grandes rios.

\section{Introduction}

The use of fishing resources in the Amazon has only been made from the experiences acquired daily from fishing and in riverine life, with the contribution of scientific knowledge being negligible for its sustainable development. The work carried out by Petrere in 1982, and its attendant publications (Petrere 1983a,b, 1985) are the only consistent source of information, on a macro scale, that are useful to subsidize fishing management in the area, while other studies are locally or temporally restricted. The discontinuity in the collection of statisti- cal data since 1986 and the lack of analyses about the distribution of fishing resources in this period on a macro scale jeopardized this initial effort of evaluation, which is reassumed in the present work.

The analysis of the natural production of fish populations on a macro scale is important for discriminating general patterns that can represent important biases in the temporal or spatial micro scales analysis. By the same reasoning, this analysis is important for guiding management decisions affecting fishing resources in a wide area 
like Central Amazon. Until now, such analysis was only carried out by Petrere (1983), which produced an analysis that will be used here as a reference and whose model will also be tested with data from 1994 to 1996.

Thus, the objective of this work is to test a hypothesis about fishing and environmental variables which determine fishing production landed in Manaus and to evaluate the relative abundance of commercial fish in the different sub-systems in Central Amazon.

\section{Material and Methods}

Trained collectors accompanied the fishing landings in the central landing port of Manaus, located at the Feira do Panair. Based on the information gathered, the following variables were used in this work: date of arrival; name of the boat; fishing ground; number of fishermen; days of fishing; catch per fish species; amount of fuel and lubricants used and amount of ice acquired.

The calculation of the catch effectively landed (on a weight basis) followed the procedures of Merona and Bittencourt (1988), considering that it is $10 \%$ superior to the amount declared.

The daily level of the rivers in stations selected by region (Figure 1), were supplied by the National Agency for Water and Electric Energy (ANEEL - www.aneel. gov.br) for the whole period. However, as the lack of samples for some days could seriously bias the monthly average, we opted for calculating mean values from the levels registered on the days 14,15 and 16 of each month, considering lost dates from months without some of these days.

The catch per unit of effort (CPUE) was obtained by two methods: the first was by the traditional approach, where the validated unit of effort, number of fishermen

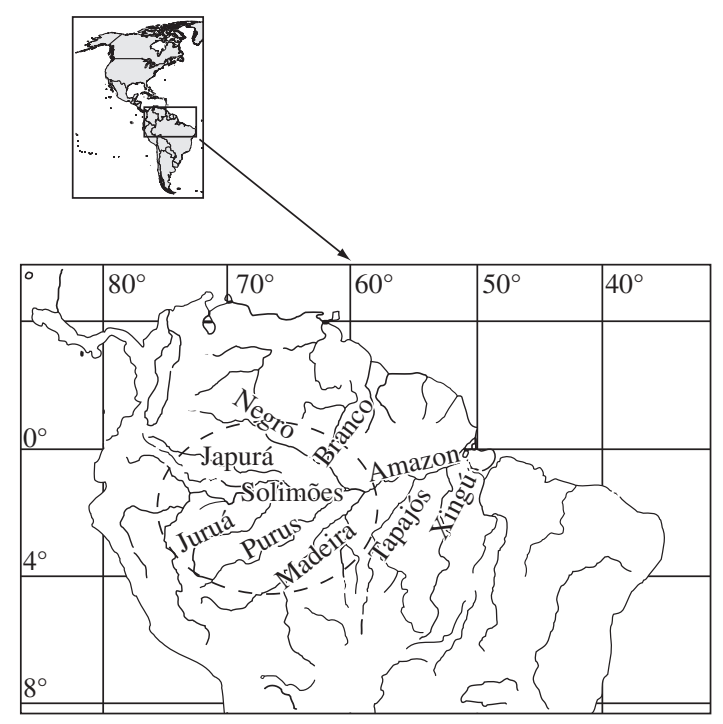

Figure 1. Map of the Amazon area exploited by Manaus fishing fleet with indication of the main rivers. days of fishing (Petrere, 1978; Batista, 1998), is the capture divisor, and the results analyzed in terms of relative abundance. The second method was through application of a linear general model, standardizing the effort with use of dummy variables for the discrete variables originally presented in the model (Kleinbaum et al. 1988). In this method, continuous variables were transformed in neperian logarithms. The following statistical model was tested:

$$
\begin{aligned}
& \mathrm{IC}=\mu+\alpha_{\mathrm{t}}+\beta_{1}\left(\mathrm{X}_{1}-\overline{\mathrm{X}}_{1}\right)+\beta_{2}\left(\mathrm{X}_{2}-\overline{\mathrm{X}}_{3}\right)+ \\
& \beta_{3}\left(\mathrm{X}_{3}-\overline{\mathrm{X}}_{3}\right)+\beta_{4}\left(\mathrm{X}_{4}-\overline{\mathrm{X}}_{4}\right)+\beta_{5}\left(\mathrm{X}_{5}-\overline{\mathrm{X}}_{5}\right)+\varepsilon_{\mathrm{tk}}
\end{aligned}
$$

where:

IC - index of capture, given by $\mathrm{C}_{\mathrm{t}}$;

$\mu$ - overall mean of the transformed capture index;

$\alpha_{t}$ - the relative abundance in year $t$ in relation to the general average;

$\beta_{1}, \beta_{2}, \beta_{3}, \beta_{4}$, and $\beta_{5}$ - regression coefficients;

$\mathrm{X}_{1}$ - covariate (number of fishermen days of fishing);

$\mathrm{X}_{2}$ - covariate (diesel consumption in liters);

$\mathrm{X}_{3}$ - covariate (distance from the fishing ground from Manaus, in km);

$\mathrm{X}_{4}$ - covariate (amount of ice consumed, in ton);

$\mathrm{X}_{5}$ - covariate (mean level of the river);

$\varepsilon_{\mathrm{tk}}$ - random error of the deviations, with a normal distribution.

Two dummy variables were generated in order to designate the levels of $\alpha_{t}$, being the type $(1,0)$ for the year 1994, $(0,0)$ for the year 1995 and $(0,1)$ for the year 1996.

The residuals of the final model represent the portion of the variance not explained by the variables of effort and environment that remained significant, and were interpreted as indicative of relative abundance. After having verified the homocedasticity of the data, these residuals were used in a simple analysis of variance, with the regions as factors. Whenever significant differences were found, mean values were analyzed by the test of least significant difference (LSD), and differences were considered significant at the level of $10 \%$.

To compare the capture indices among years, we used as a basis an index estimated for an arbitrary common situation, where a value of zero was assigned to all continuous variables, and the respective values for each year were assigned to the dummy variables.

Statistical programs, with theoretical frameworks of Sokal and Rohlf (1981), Kleinbaum et al. (1988) and Tabachnick and Fidell (1996) carried out the regression and the variance/covariance analysis, as well as the presupposition tests of such analyses.

\section{Results}

Initially the above models were tested, which were developed by Petrere (1983) to predict the landings made in Manaus:

- System Solimões-Amazonas (extensive floodplain): $\log \mathrm{C}=-6.0114+2.3409 \log \mathrm{f}$ 
- Main tributaries (normal floodplain):

$\log \mathrm{C}=-1.0553+0.2574 \mathrm{Z}_{1}-0.2536 \mathrm{Z}_{2}+1.28301$

$\log \mathrm{f}$

being $\mathrm{C}$ the corrected annual capture of the river $\mathrm{j}$ in the year $i ; Z_{1}$ and $Z_{2}$ are dummy variables, that indicate the group of rivers analyzed: for the Juruá and Jutaí Rivers it was (1.0), for the Negro, Branco and Purus Rivers it was $(0.1)$ and for the Madeira River it was $(0.0)$; $\mathrm{f}$ is the sum of the number of fishermen that fished every year in each river.

The adjustment of the model for the main tributaries showed a good fit, except for Purus in 1995 and 1996 (Figure 2), which showed several changes in the characteristics of the fishing in the period. Also, the model for the Solimões-Amazonas system presented predictions consistently below observed patterns.

A new capture index had its parameters selected and estimated, resulting in the following final model, which was significant $(\mathrm{P}<0.01)$, with all variables displaying significant contribution at the minimum level of $0,01 \%$ (Table 1):

This model presented $\mathrm{R}=0.377\left(\mathrm{~F}_{6.4664}=469.75\right.$; $\mathrm{p}<0.01$ ), and the residuals showed an adequate distribution. Thus, the model explained about $38 \%$ of the variance between trips and the residuals for each trip were calculated and used as the index of relative capture.

$$
\begin{aligned}
& \mathrm{IC}=\mu+\alpha_{\mathrm{t}}+\beta_{1}\left(\mathrm{X}_{1}-\overline{\mathrm{X}}_{1}\right)+\beta_{2}\left(\mathrm{X}_{2}-\overline{\mathrm{X}}_{3}\right)+ \\
& \beta_{3}\left(\mathrm{X}_{3}-\overline{\mathrm{X}}_{3}\right)+\beta_{4}\left(\mathrm{X}_{4}-\overline{\mathrm{X}}_{4}\right)+\varepsilon_{\mathrm{tk}}
\end{aligned}
$$

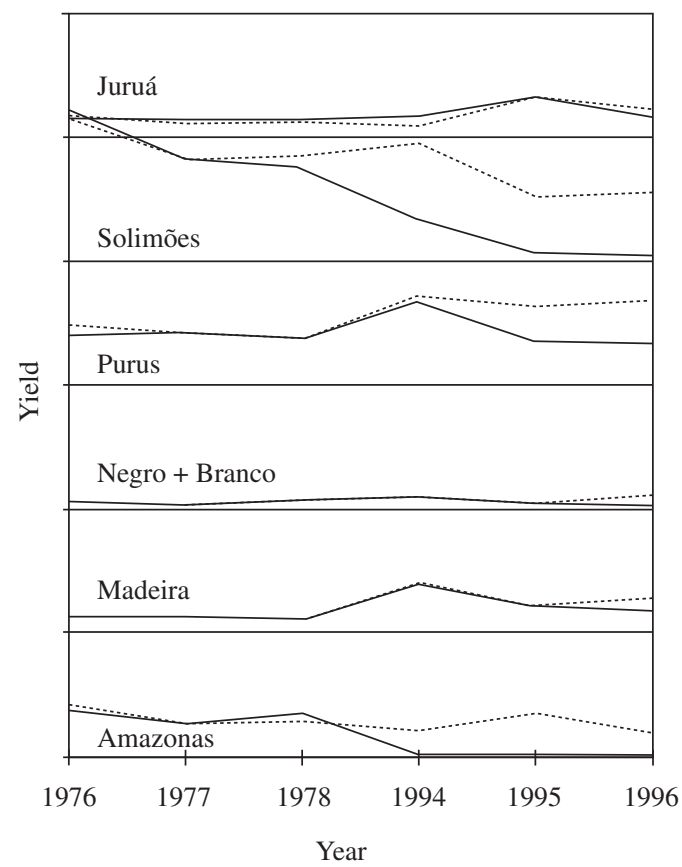

Figure 2. Temporal variation in the observed and estimated landing through the models of Petrere (1983), discriminating the rivers of origin of the fish. The thick line represents the predicted data and the fine line the observed data.
The first question appraised was the variation of the index among years, which showed a positive variation during the studied period. This variation was equal to $8.7 \%$ between 1994 and 1995, and equal to $81 \%$ between 1995 and 1996. Following that, we carried out an analysis of variance with the residuals, with the sub-systems as factors, whose results showed a significant difference among levels $(\mathrm{P}<0.01)$.

The analysis a posteriori (Table 2) showed that the Purus, Juruá and Madeira Rivers are sub-systems with higher, but quite similar, capture indexes. Middle Solimões, Japurá and Middle Amazonas form a group of sub-systems with intermediary magnitude, followed by the Low-Solimões sub-system, as well as the Negro River, which presented the smallest indices of capture.

\section{Discussion}

Fishing is an activity that provides an important biological sampling for the whole Amazon basin. It is assumed that all the fishermen are trying to obtain the largest revenue and profit in all the rivers reached by the fleet, generating samples comparable with each other. This feature is important to validate the analysis, allowing us to obtain a general approach of the production in the basin. Such an approach is economically unviable by means of experimental fishing, besides being extremely difficult to operate in such a large and diverse environment.

Fishermen in the Amazon go fishing in preferred targets and select sub-systems and fishing grounds in agreement with their beliefs about the abundance of the resource there. However, if the fishing was unsuccessful they fish on a similar target (Batista, 1998). The fishing ships generally possess several types of fishing gear, although production can be carried out using a single type of gear. The fishermen are enabled technically to explore a diverse and dynamic environment, using several types of gear that in turn, are used with varied techniques. Different from the fishing ships, whose movements are quite limited by the hydrodynamic and bathymetric features of the rivers, the several environments of a fishing area are equally accessible to the fishermen, since their operational base is the canoe. In any case, fishing occurs in accordance with the available resource in the

Table 1. Estimated coefficients for each variable, standard error (se) and the associated level of significance in the model of the capture index.

\begin{tabular}{lrcc}
\hline \multicolumn{1}{c}{ Item } & Coefficient & se & Significance \\
\hline I intercept & -2.0297 & 0.1599 & $<0.0001$ \\
$\alpha_{2}$ & -0.0831 & 0.0301 & 0.0058 \\
$\alpha_{3}$ & 0.5094 & 0.0319 & $<0.0001$ \\
$\ln ($ dist $)$ & 0.0974 & 0.0170 & $<0.0001$ \\
$\ln ($ gelo $)$ & 0.6401 & 0.0258 & $<0.0001$ \\
$\ln ($ nvrio $)$ & 0.0556 & 0.0161 & 0.0006 \\
$\ln (n p * d p)$ & 0.3518 & 0.0237 & $<0.0001$ \\
\hline
\end{tabular}


Table 2. Significance test of contrast of the capture index through the least significant difference (LSD) among the levels that form the factor sub-system. Below the diagonal, grey lines indicate cells with significant contrast $(\mathrm{P}<0,05)$.

\begin{tabular}{|c|c|c|c|c|c|c|c|c|c|c|c|}
\hline \multicolumn{2}{|c|}{ Sub-system } & MAM & MAD & HAM & NEG & LSO & PUR & MSO & JAP & JUR & HSO \\
\hline $\begin{array}{l}\text { Medium } \\
\text { Amazonas }\end{array}$ & MAM & - & 0.051 & 0.244 & 0.002 & 0.024 & 0.065 & 0.914 & 0.575 & 0.184 & 0.783 \\
\hline Madeira & MAD & 0.051 & - & $<0.001$ & $<0.001$ & $<0.001$ & 0.557 & $<0.001$ & $<0.001$ & 0.040 & 0.077 \\
\hline $\begin{array}{l}\text { High } \\
\text { Amazonas }\end{array}$ & HAM & 0.244 & $<0.001$ & - & $<0.001$ & $<0.001$ & $<0.001$ & $<0.001$ & 0.486 & $<0.001$ & 0.605 \\
\hline Negro & NEG & 0.002 & $<0.001$ & $<0.001$ & - & $<0.001$ & $<0.001$ & $<0.001$ & $<0.001$ & $<0.001$ & 0.048 \\
\hline $\begin{array}{l}\text { Low } \\
\text { Solimões }\end{array}$ & LSO & 0.024 & $<0.001$ & $<0.001$ & $<0.001$ & - & $<0.001$ & $<0.001$ & 0.0247 & $<0.001$ & 0.190 \\
\hline Purus & PUR & 0.065 & 0.557 & $<0.001$ & $<0.001$ & $<0.001$ & - & $<0.001$ & $<0.001$ & 0.068 & 0.090 \\
\hline $\begin{array}{l}\text { Medium } \\
\text { Solimões }\end{array}$ & MSO & 0.914 & $<0.001$ & $<0.001$ & $<0.001$ & $<0.001$ & $<0.001$ & - & 0.266 & $<0.001$ & 0.675 \\
\hline Japurá & JAP & 0.575 & $<0.001$ & 0.487 & 0.001 & 0.025 & $<0.001$ & 0.266 & - & 0.006 & 0.889 \\
\hline Juruá & JUR & 0.184 & 0.040 & $<0.001$ & $<0.001$ & $<0.001$ & 0.068 & $<0.001$ & 0.006 & - & 0.187 \\
\hline $\begin{array}{l}\text { High } \\
\text { Solimões }\end{array}$ & HSO & 0.783 & 0.077 & 0.605 & 0.048 & 0.190 & 0.090 & 0.675 & 0.889 & 0.187 & - \\
\hline
\end{tabular}

sub-system chosen, be it the main objective of the fishing or not, and it finishes when the resources invested in the operation (e.g. ice or space in the box) are fully used or exhausted.

The contribution of the variables related to the effort and to the environment should also be considered or pondered, as well as the inter-annual variation in the availability of the fishing resources. The weighing of the capture for a unit of effort is traditionally used as a form of obtaining an index of relative capture. However, the lack of linearity, the variation of catchability with abundance or the wide fraction of the variance that is not explained in the relationship between CPUE and abundance (Paloheimo and Dickie, 1964; Cooke, 1985; Shardlow, 1993), can lead to potentially misleading evaluations (Peterman and Steer, 1981; Shardlow, 1993). Since the work of Gavaris (1980), linear models have been increasingly used in order to contemplate these prerequirements, with more information being requested, generating a demand for identifying the variables that explain most of the variance (Vignaux, 1996). This can be done through variables that are relatively easy to follow, such as size of the ships and information about the effort (Palsson and Durrenberger, 1982), even though such variables do not explain an acceptable or significant minimum in some fisheries (Hilborn and Ledbetter, 1985, Merona and Gascuel, 1993). Nevertheless, in all cases, the elaboration of a specific model represents a development process that is sensitive to the dynamics of the fishing activity and in the availability of information. This fact allows the obtention of an index of relative capture that indicates non-biased variations in the abundance of fishing resources, which is important for its management.

In the present work, we used variables associated with effort (number of fishermen times days fishing) that were the best ones in papers that aimed to determine the unit of effort for regional fishing (Petrere, 1978; Batista, 1998). We also used other variables that presented good adjustments (amount of ice) or not (amount of diesel) seeking to evaluate the contributions to the model. The result was coherent with the previous information, for the contribution of all the variables, except for the amount of diesel consumed, were significant for the model indicating robustness in the method for these type of data.

The portion not explained by the model is within the residuals, which contains about $63 \%$ of the total observed variance in this case. The inter-annual variation in the yield per trip and the seasonal variations associated with the variation in the level of the river were successfully contemplated in the model. This last variable is an environmental reference of the complex variations that are associated with the river pulse (Junk et al., 1989). This variable certainly is important due to its co-linearity with variables that directly affect fish production and fishing, but although the environmental contribution could surely be improved, it already contributed significantly to the model.

The residuals from the model could represent the relative variation in the abundance of the fishing resources as a whole. More complex processes associated with effort (e.g. the master's ability in conducting the fishing process) or to the river pulse (e.g. forest area flooded each month), might be the determining part of the variance contained in the residuals. However, this variance can also be regarded as being randomically distributed in space and time, so that the relative variation that is the target of our analysis was considered pertinent and viable.

In this context, the existence of a significant difference among sub-systems, associated to the similarity of the mean values among the Purus, Madeira and Juruá sub-systems, suggests that the tributaries of the right-hand-side margin are similar and exhibit greater 
abundance, being different from the main course of the Solimões-Amazonas and Negro Rivers, which showed the smallest values. However, at least the first case is not linked to environmental characteristics, but with the larger exploitation by linear kilometer of the river. The riverine population also heavily uses this area for agricultural activities in the floodplain and it exhibits the highest level of inhabitation.

In the analysis of the productivity of the system, it is important to underscore two concepts. First, Vannote et al. (1980) proposed the concept of river continuum whereby morphologic and biotic characteristics of the system are related to a gradation in the availability of organic matter as the order of the rivers is increased. As far as fish populations are concerned, the concept foresees a transition of insectivorous predators in the rivers of smaller order for herbivore and detritivorous in the rivers of larger order. This last group usually transforms the alochthonous organic matter for incorporation to the biotic aquatic system. The second concept was proposed by Junk et al. (1989), who synthesized the interaction of the flooded forest with the main course of the rivers in terms of its productivity through the concept of "flood " pulse. Accordingly to this concept, the variation in the level of the rivers and the consequent flooding of the marginal areas would be the main factor controlling the existent adaptations and the year-to-year productivity observed in a system. For the fish fauna, the characteristics of the aquatic/terrestrial transition zone (ATTZ) are fundamental, as it defines the availability of food and habitats for youths and adults of numerous species.

Although in the specific formulation there are divergent aspects in the two concepts (Welcomme, 1990; Junk, 1997), basic aspects of both can be put together for evaluating the productive system, treating them as being complementary in two defined contexts. The concept of fluvial continuity accepts that disturbances along the continuum determine new characteristics down river of the disturbed course. On the other hand, the impact of the flood pulse as an adaptive event would depend on the characteristics and of the dimension of the flooded area, being also determined by the duration and stability of the fluvial cycle to each pulse. This integration of the concepts is important in the present context, because the species that form most of the fish marketed in the area use the flooded areas as well as the main channel of the basin and its sub-basins along different moments of its life history (Batista, 1998). However, the different sub-systems could present limnological particularities that can individualize them in terms of productivity (Sioli,1984; Junk, 1997).

Availability of nutrients and of organic matter is the basis for fishing production; an observation that is more marked in systems with a strong presence of detritivorous and predator species (Araújo-Lima et al., 1995). The affinity of particular sub-systems, such as Purus and Juruá and, on a smaller scale, the Madeira (which is referred here as the low Madeira, enclosing the flood plains of the right margin as well as the Tupinambarana island and Canumã river), is defined by the similarity of the floodplains that occur in these sub-systems. Nevertheless, the impact of non-managed fishing can reduce capture productivity as low as the intermediary level of Medium Solimões or at the depressed level of Low Solimões, even though both sub-systems also possess extensive floodplain areas. However, these two sub-systems showed low fishing productivity due to anthropomorphic impact, be it associated with an inadequate fishing pressure generated by the disorder in the system of current fishing exploration, or by degradation of the floodplain areas for extraction and agricultural activities.

This spatial variation of fishing productivity supports the thesis of the importance of the floodplain in the aquatic organic production in Central Amazonia and, thus corroborates the pulse theory. On the other hand, Petrere (1983) tested a model that considered the magnitude of the flooded area per year and the significance of the factor "lake" in the prediction of fishing production. He was not able to detect an affect neither for flooded areas nor for the correlation between effort and size of the flooded area where the fishing took place; however, he found a significant effect for the variable "lake". These results already indicated that the fishermen fished in different lakes, independently of the size of its flooded area (Petrere, 1983); it also showed that these lakes differed in a factor different from the "flooded" area, resulting in varied fishing productivity.

Merona and Gascuel (1993) found an effect of the level of the river in previous years on the mean fishing production, in a fishing place in which the fishing effort did not affect the production significantly (The Careiro island, located about $20 \mathrm{~km}$ from Manaus). This result indicates that the variance of the effort does not contribute to prediction of the production in fishing places close to the consuming center; it also shows that rainy variation might be a powerful factor, although its effects are poorly understood. Pluviometric variations can determine the productivity of the system in a way associated to the autochthonous contribution of organic matter of the flooded forest, due to the positive relationship between the area of the forest and the amount of water it receives during the annual flooding period.

Notwithstanding this complexity, the observed spatial affinities seem to indicate that the sub-system is a small unit to embrace the most exploited resources in the area which, in turn, determine the magnitude of the professional fishing production. The hydrographic basin is the recommended unit of study for water resources, a choice recently recognized in the approved national politics of water resources (law 9433 of 8/01/1997) and a promising perspective for the rational use of water and its renewed resources. However, it is not advisable to turn these extremes into a dogma, because mega-basins such as the Amazonian are very diverse and complex to be subject to the same human and natural activities through time. On the other hand, the minimum size of 
the aquatic bodies for management purposes would not correspond to a great tributary or section of a large river, since the biological interactions in a dynamic system seem to determine density gradients, but on a much larger scale. The dimension of the managed area certainly will have to be defined by means of a global evaluation of the unit of use and of resource cycling. To do so, it is necessary to carry out management in an adaptive form, case-by-case, trying to learn with the results of the implemented actions or simply from the natural variations that arise.

Obviously there is little information to determine definitive patterns, being rare the opportunity to find information about spatial-temporal variations on aquatic resources in the Amazonian waters with a minimum of methodological standardization, which allows us to have a general overview of the system. It is recommended that the evaluation be maintained in the area under the form of environmental and fishing monitoring, which should lead to more consistent strategies for the maintenance of sustainable development of fishing in the area.

Acknowledgments - This research was carried out at the Federal University of Amazonas and supported by the Conselho Nacional de Desenvolvimento Científico e Tecnológico, Superintendência para o Desenvolvimento da Amazônia, Fundação Banco do Brasil e Fundo Nacional do Meio Ambiente. The research described in this article formed part of V.S.B.'s doctoral thesis at the INPA/FUA (www.inpa.gov.br).

\section{References}

ARAUJO-LIMA, CARM, AGOSTINHO, AA. and FABRÉ, NN., 1995. Trophic aspects of fish communities in Brazilian rivers and reservoirs.. In TUNDISI, JG., BICUDO, CEM., TUNDISI, TM. (eds.) Limnology in Brazil. ABC/SBL, São Paulo p. 105-136

BATISTA, VS., 1998. Distribuição, dinâmica da pesca e dos recursos pesqueiros na Amazônia Central. Unpublished doctoral thesis, INPA/FUA, 291p.

COOKE, JG., 1985. On the relationship between catch per unit effort and whale abundance. Report of the International Whaling Commission, vol. 35, p. 511-519.

GAVARIS, S., 1980. Use of a multiplicative model to estimate catch rate and effort from commercial data. Can. J. Fish. Aquat. Sci. vol. 37, p. 2272-2275.

HILBORN, R. and LEDBETTER, M., 1985. Determinants of catching power in the British Columbia salmon purse-seine fleet. Can. J. Fish. Aquat. Sci. vol. 42, p. 51-56.

JUNK, WJ., 1997. The Central Amazon Floodplain: Ecology of a pulsing system. Ecological Studies, Springer-Verlag. Berlin, p. 126, 525p.

JUNK, WJ, BAYLEY, PB. and SPARKS, RE., 1989. The flood pulse concept in river-floodplain systems. Can. J. Fish. Aquat. Sci. Special Publication, vol. 106, p. 110-127.

KLEINBAUM, DG., KUPPER, LL. and MULLER, KE., 1988. Applied regression analysis and other multivariable methods. PWS-KENT Publishing Co., Boston. 718p.
MERONA, B. and BITTENCOURT, MM., 1988. A pesca na Amazônia através dos desembarques no mercado de Manaus: Resultados preliminares. Mem. Soc. Cienc. Nat. La Salle, vol. 48, supl. 2, 433-453.

MERONA, B. and GASCUEL, D., 1993. Effects of flood regime and fishing effort on the overall abundance of an exploited fish community in the Amazon floodplain. Aquatic Living Resources, vol. 6 , no. 1, p. 97-108.

PALOHEIMO, JE. and DICKIE, LM., 1964. Abundance and fishing success. Rapp. P.-C. Reun. Cons. Perm. Int. Explor. Mer vol. 155 , no. 28 , p. $152-163$.

PALSSON, G. and DURRENBERGER, P., 1982. To dream of fish: the causes of Icelandic skippers fishing success. $J$. Anthropol. Res., vol. 38, no. 2, p. 227-242.

PETERMAN, RM. and STEER, GJ., 1981. Relation between sport-fishing catchability coefficients and salmon abundance. Trans. Am. Fish. Soc., vol. 110, no. 5, p. 585-593.

PETRERE, Jr., M., 1978. Pesca e esforço de pesca no estado do Amazonas. I - Esforço e captura por unidade de esforço. Acta Amazonica, vol. 8, no. 3, p. 439-454.

-, 1982. Ecology of the fisheries in the river Amazon and its tributaries in the Amazonas state (Brazil). (Ph. D. thesis) University of East Anglia. 96p.

-, 1983a. Relations among catches, fishing effort and river morphology for eight rivers in Amazonas State (Brazil), during 1976-1978. Amazoniana, vol. 8, no. 2, p. 281-296.

-, 1983b. Yield per recruit of the tambaqui, Colossoma macropomum Cuvier, in the Amazonas State, Brazil. J Fish Biol., vol. 22, no. 2, p. 133-144.

-, 1985. A pesca comercial no rio Solimões-Amazonas e seus afluentes: análise dos informes do pescado desembarcado no Mercado Municipal de Manaus (1976-1978). Ciênc. Cult. vol. 37, no. 12, p. 1987-1999.

SHARDLOW, TF., 1993. Components analysis of a densitydependent catchability coefficient in a salmon hook and line fishery. Can. J. Fish. Aquat. Sci., vol. 50, p. 513-520.

SIOLI, H., 1984. The Amazon and its main affluents: Hydrography, morphology of the river courses, and river types. In SIOLI, H. (ed.) The Amazon: limnology and landscape ecology of a mighty tropical river and its basin. The Hague, W. Junk Publications, Netherlands, p. 127-166.

SOKAL, RR. and ROHLF, FJ., 1981. Biometry. The principles and practice of statistics in biological research. W.H. Freeman and Company, New York, 859p.

TABACHNICK, BG. and FIDELL, LS., 1996. Using multivariate statistics. HarperCollins College Publishers Inc., New York, 880p.

VANNOTE, RL., MINSHALL, GW., CUMMINS, KW., SEDELL, JR. and CUSHING, CE., 1980. The river continuum concept. Can. J. Fish. Aquat. Sci. vol. 37, p. 130-137.

VIGNAUX, M., 1996. Analysis of vessel movements and strategies using commercial catch and effort data from the New Zealand hoki fishery. Can. J. Fish. Aquat. Sci. vol. 53 no. 9, p. 2126-2136.

WELCOMME, RL., 1990. Status of fisheries in South American rivers. Interciencia, vol. 15, no. 6, p. 337-345. 